IZA DP No. 8160

Rent Seeking and the Excess Burden of Taxation

Nava Kahana

Doron Klunover

April 2014 


\title{
Rent Seeking and the Excess Burden of Taxation
}

\author{
Nava Kahana \\ Bar-llan University \\ and IZA \\ Doron Klunover \\ Bar-Ilan University
}

\section{Discussion Paper No. 8160 \\ April 2014}

\author{
IZA
}
P.O. Box 7240
53072 Bonn
Germany

Phone: +49-228-3894-0

Fax: +49-228-3894-180

E-mail: iza@iza.org

Any opinions expressed here are those of the author(s) and not those of IZA. Research published in this series may include views on policy, but the institute itself takes no institutional policy positions. The IZA research network is committed to the IZA Guiding Principles of Research Integrity.

The Institute for the Study of Labor (IZA) in Bonn is a local and virtual international research center and a place of communication between science, politics and business. IZA is an independent nonprofit organization supported by Deutsche Post Foundation. The center is associated with the University of Bonn and offers a stimulating research environment through its international network, workshops and conferences, data service, project support, research visits and doctoral program. IZA engages in (i) original and internationally competitive research in all fields of labor economics, (ii) development of policy concepts, and (iii) dissemination of research results and concepts to the interested public.

IZA Discussion Papers often represent preliminary work and are circulated to encourage discussion. Citation of such a paper should account for its provisional character. A revised version may be available directly from the author. 
IZA Discussion Paper No. 8160

April 2014

\section{ABSTRACT}

\section{Rent Seeking and the Excess Burden of Taxation*}

The social costs of rent seeking are generally evaluated with respect to rent dissipation. A common assumption is complete rent dissipation so that the value of a contested rent is the value of social loss. When rent seekers earn taxable income, there is interdependence between the social cost of rent seeking through rent dissipation and the excess burden of taxation. Through the addition of substitution to rent seeking beyond leisure, rent seeking increases the excess burden of taxation under risk neutrality when leisure is non-inferior. We derive a condition for rent seeking to increase the excess burden of taxation under risk aversion. Our conclusion is that, when rent seekers can earn taxable income, rent seeking is more socially costly than is inferred from contest models alone, because of an increased excess burden of taxation.

JEL Classification: $\quad \mathrm{H} 2$

Keywords: rent seeking, excess burden of taxation, welfare cost of taxation, size of government

Corresponding author:

Doron Klunover

Bar-Ilan University

Department of Economics

Ramat Gan 5290002

Israel

E-mail: Doron.Kluhovrd@biu.ac.il

\footnotetext{
* Previous versions of this paper were presented at the Silvaplana workshop in political economy and the Public Choice Society annual meetings. We thank participants for helpful comments.
} 


\section{Introduction}

Gordon Tullock (1967) observed that a social cost is incurred when time and resources are attracted into contesting available benefits or rents. The primary concern of the literature (see Congleton, Hillman, and Konrad 2008) that followed on from Tullock's observation has been evaluation of the social cost of rent seeking. With no official data on rent seeking available and contested rents in general not observable, the approach to measurement of the social cost of rent seeking has been through modelling the behavior of rent seekers in the theory of contests (Konrad, 2009; Long, 2013). Empirical studies have used the conclusions from the models to infer social costs through dissipation of rents, usually under the assumption of complete dissipation (see Hillman, 2013).

The studies of the social cost of rent seeking have had in common the assumption that contests occur in isolation from other sources of income and from leisure. Yet in general rent seekers can also earn incomes in labor markets and allocate time to leisure. The incomes are subject to taxation. We show that when rent seekers earn - or can earn - taxable income and can allocate time to leisure, under reasonable conditions the social cost of rent seeking exceeds the social losses inferred from the presence of a rent-seeking contest alone. $^{1}$

\footnotetext{
${ }^{1}$ There has been recognition that rent seeking is included in possible allocation of time. See Weiss (2009). The interdependence between the social costs of rent seeking and the excess burden of taxation has not been studied.
} 
The excess burden of taxation is associated with the Harberger triangle (see Harberger, 1964; Hines, 1999). In the special case in which the compensated labor supply is linear, the excess burden of taxation can be measured by using a formula for the Harberger triangle that includes the tax rate and the compensated elasticity of labor supply (for an exposition, see Hillman, 2009 chapter 4). We use the equivalent variation to measure the excess burden of taxation. $^{2}$

In section 2 we add a rent-seeking opportunity to time allocation options of earning taxable income or leisure. We do not introduce further time allocation options such as home production or an informal sector, which unlike rent seeking can be non-strategic and risk-free. In section 3, with leisure non-inferior, we obtain the quite intuitive result using the equivalent variation that the excess burden of taxation is greater in the presence of a rentseeking opportunity. The core intuition is that a tax on earned income decreases the opportunity cost of leisure and when present, also of rent seeking. Therefore time is substituted from labor to leisure but also from labor to rent seeking. An adverse effect of a tax on earned income on a rent seeker is that, unlike leisure, the expected return from participating in a strategic rent

\footnotetext{
${ }^{2}$ Although the formula for the area of the Harberger triangle can be used as an approximation for measuring the specific excess burden with infinitesimal rate of taxation, because of the possible different direction and magnitude of errors in consequence of using an approximation, to compare between different excess burdens, we require an accurate measure such as the equivalent variation. On measurement of the excess burden, see Willig (1976) and Hausman (1981). For a textbook exposition, see Hillman (2009, chapter 4).
} 
seeking contest may not increase when substituting more time into a contest. With identical individuals the expected return is unchanged. These effects increase the excess burden of taxation. We provide a more technical detailed explanation of the increase in the excess burden of taxation after a formal proof. $^{3}$

In section 4 we introduce risk-aversion. Rent seeking in addition to being strategic is also risky, because the return from rent seeking is not certain. The excess burden of taxation with risk aversion regarding rent seeking includes the effect of risk on time substitution and a reevaluation of the uncertain income from rent seeking due to a change that can occur in the individual's risk premium. With additive utility, constant absolute risk aversion is a sufficient condition for replication of the result that rent seeking increases the excess burden of taxation. ${ }^{4}$

Sections 3 and 4 focus on technical proofs. Section 5 notes applicability of the conclusions to extensions of the basic rent-seeking model. We note studies in which, in distinction to the separation common in the literature,

\footnotetext{
${ }^{3}$ Rent seeking increases the excess burden of taxation and at the same time, because of the greater excess burden of taxation, the social cost of rent seeking is greater when rent seekers earn taxed productive income. There is only one additional social loss.

${ }^{4}$ Risk aversion was introduced in models of rent seeking in Hillman and Katz (1984) under the assumption of constant relative risk averstion, which results in diminashed rent-seeking outlays as risk aversion increases. More generally, risk-aversion introduces ambiguities into rent-seeking models (Skaperdas and Gan 1995; Konrad and Schlesinger, 1997; Treich 2010).
} 
recognize interdependence between issues of public finance and rent seeking. We give examples of coexistence of rent-seeking opportunities with taxable income and note the implications of our results for the socially desirable size of government.

\section{Labor supply, leisure, and rent seeking}

We begin with the standard labor-supply model of an individual who earns taxed income and confronts a labor/leisure choice with no rent seeking opportunity. The individual $i$ assigns time to leisure $l_{i}$ and time to productive work, $L_{i}=\bar{T}-l_{i}$, where $\bar{T}$ is available time, and receives a net-of-tax wage rate of $W_{i}$ per hour. The individual also has non-contestable non-labor income $M_{i}$. There is no saving. Utility $U_{i}$ depends on consumption of market goods $C_{i}$ and leisure $l_{i}$. Individual $i$ solves the time allocation problem (Becker, 1965):

$$
\max _{l_{i}} U_{i}\left(C_{i}, l_{i}\right),
$$

where $C_{i}=\left(\bar{T}-l_{i}\right) W_{i}+M_{i}$. In an interior solution,

(2) $\frac{d U_{i}}{d l_{i}}=U_{i l_{i}}-W_{i} U_{i c_{i}}=0$,

and

(3) $\frac{d^{2} U_{i}}{d l_{i}^{2}}=U_{i i_{i} l_{i}}+W_{i}^{2} U_{i c_{i} c_{i}}-2 W_{i} U_{i c_{i} l_{i}}<0$

where 


$$
U_{i k} \equiv \frac{\partial U_{i}}{\partial k}, U_{i k k} \equiv \frac{\partial^{2} U_{i}}{\partial k^{2}}, \quad k=C_{i}, l_{i}, \text { and } U_{i c_{i} l_{i}} \equiv \frac{\partial^{2} U_{i}}{\partial c_{i} \partial l_{i}}
$$

Applying the implicit function theorem in (2) results in:

(4) $\frac{\partial l_{i}}{\partial M_{i}}=\frac{U_{i l_{i} c_{i}}-W_{i} U_{i c_{i} c_{i}}}{-\frac{d^{2} U_{i}}{d l_{i}^{2}}}$

and

(5) $\quad \frac{\partial l_{i}}{\partial W_{i}}=\left(\bar{T}-l_{i}\right) \frac{\partial l_{i}}{\partial M_{i}}+\frac{U_{i c_{i}}}{\frac{d^{2} U_{i}}{d l_{i}^{2}}}$.

Leisure is a normal, neutral or inferior good according to whether $U_{i i_{i} c_{i}}-W_{i} U_{i c_{i} c_{i}}<0$, respectively. With leisure normal, the response to an increase in the net-of-tax wage is ambiguous. Under the standard assumption that, with leisure normal, the substitution effect of an increase in the net wage $\frac{U_{i c_{i}}}{\frac{d^{2} U_{i}}{d l_{i}^{2}}}<0$ dominates the income effect $\left(\bar{T}-l_{i}\right) \frac{\partial l_{i}}{\partial M_{i}}$, labor supply increases with the net-of-tax wage.

We now introduce the opportunity to contest a rent. A rent of common-value $V$ yielding only private benefit is indivisibly assigned to one successful rent seeker. ${ }^{5}$ The rent is not taxed and nor is the value of inputs

\footnotetext{
${ }^{5}$ We thus adopt the standard rent-seeking model. See Long (2013).
} 
into rent seeking a tax credit or deduction from taxes paid on productively earned income. ${ }^{6}$

The activity of rent seeking by individual $i$ requires a combination of the use of resources $x_{i} \geq 0$ and time. Use of $x_{i}$ entails assignment of $\beta_{i} x_{i}$ hours to rent seeking, where $\beta_{i}>0$. Through $\beta_{i}$ we include a measure of individual effectiveness in rent seeking. More adept rent seekers have lower values of $\beta_{i} \cdot{ }^{7}$

We use a general contest-success function. The probability that individual $i$ secures the rent $V$ is $P_{i}\left(x_{1}, \cdots, x_{i}, \cdots, x_{n}\right)$ where $x_{j} \geq 0 \quad j \neq i$ denotes resources used in the contest by others. The function $P_{i}$ has the usual properties of:

${ }^{6}$ Glazer and Konrad (1999) describe taxation in the context of rent seeking. If the benefit from rent seeking is taxed independently of the tax on labor income, the value of the rent $\mathrm{V}$ is diminished by the value of the tax payment with no effect on our results. Domar and Musgrave (1944) studied the effects of an proportional tax on both certain and uncertain income, which in our case would entail taxing uncertain income from rent seeking and certain labor income at the same rate. They concluded that, because the tax absorbs part of the risk by decreasing the variance of expected income, in some circumstances investment in risky assets increases when the rate of taxation increases. In our case only labor income is taxed and the taxation therefore does not reduce the variance of expected income.

7 Our formulation acknowledges that time itself is in general not enough as an input into rent seeking. See also Epstein and Hefeker (2003), who propose two substitutable inputs for influencing the probability of rent-seeking success. Our inputs are complementary. 
(6) $\quad 0<P_{i}<1 \quad \forall x_{i}>0, \quad \frac{\partial P_{i}}{\partial x_{i}}>0, \quad \frac{\partial^{2} P_{i}}{\partial x_{i}{ }^{2}}<0, \quad \frac{\partial P_{i}}{\partial x_{j}}<0$ and for $x_{1}=x_{i} \cdots=x_{n}$

$$
P_{i}=\frac{1}{n} \forall i=1, \ldots, n
$$

Post-contest income and consumption depend on whether an individual has been successful in rent seeking and are therefore state-contingent. ${ }^{8}$ After the outcome of the rent-seeking contest has been determined, the successful rent seeker will consume

$C_{i}^{V}=\left(\bar{T}-l_{i}-\beta_{i} x_{i}\right) W_{i}+M_{i}+V-x_{i}$

and will have resulting utility

$U_{i}^{V}=U_{i}\left(C_{i}^{V}, l_{i}\right)$

Consumption of an unsuccessful rent seeker will be:

$$
C_{i}^{-V}=\left(\bar{T}-l_{i}-\beta_{i} x_{i}\right) W_{i}+M_{i}-x_{i},
$$

with utility

$$
U_{i}^{-V}=U_{i}\left(C_{i}^{-V}, l_{i}\right)
$$

The expected utility of individual $i$ is:

$$
E U_{i}\left(x_{i}, l_{i}, x_{-i} ; W_{i}, \beta_{i}, M_{i}, V\right)=P_{i} U_{i}\left(C_{i}^{V}, l_{i}\right)+\left(1-P_{i}\right) U_{i}\left(C_{i}^{-V}, l_{i}\right),
$$

where $x_{-i}=\left(x_{1}, \cdots, x_{i-1}, x_{i+1}, \cdots, x_{n}\right)$.

Certainty equivalent consumption $\tilde{C}_{i}$ satisfies:

\footnotetext{
8 We do not consider the possibility of insurance. In practice, insurance regarding the outcome of partipcation in rent-seeking contests is not available.
} 
(8) $\quad E U_{i}=U_{i}\left(\tilde{C}_{i}, l_{i}\right)=\tilde{U}_{i}$.

With risk aversion, $U_{i c_{i} c_{i}}<0$ and

(9) $\quad \tilde{C}_{i}=C_{i}^{-V}+P_{i} V-\varepsilon_{i}$

where $\varepsilon_{i} \geq 0$ is the risk premium. ${ }^{9}$

Before the outcome of the rent-seeking contest is known, individual $i$ solves:

(10) $\max _{X_{i}, \underline{l}_{i}} E U_{i}\left(x_{i}, l_{i}, x_{-i} ; W_{i}, \beta_{i}, M_{i}, V\right)=\max _{x_{i}, l_{i}} \tilde{U}_{i}\left(x_{i}, l_{i}, x_{-i} ; W_{i}, \beta_{i}, M_{i}, V\right)$.

With identical individuals, so that $x_{1}=x_{2}=\cdots=x_{n}=x$ and $l_{1}=l_{2}=\cdots=l_{n}=l$, in a symmetric Nash equilibrium,

$$
\frac{\partial \tilde{U}}{\partial x}=\tilde{U}_{\tilde{c}}\left(\frac{\partial P}{\partial x} V-\frac{\partial \varepsilon}{\partial x}-(1+\beta W)\right)=0
$$

and

$$
\frac{\partial \tilde{U}}{\partial l}=\tilde{U}_{l}-\left(W+\frac{\partial \varepsilon}{\partial l}\right) \tilde{U}_{\tilde{c}}=0
$$

With $\tilde{U}_{\tilde{c}}>0,(11)$ is equivalent to:

(13) $\frac{\frac{\partial P}{\partial x} V-\left(\frac{\partial \varepsilon}{\partial x}+1\right)}{\beta}=W$.

We denote by $\left(x^{*}, l_{R}^{*}\right)$ the solution to $(12)$ and $(13)$ and by $l_{N R}^{*}$ and $C\left(l_{N R}^{*}\right)$ the solution to (2). In the remainder of the paper we consider only interior

${ }^{9}$ With risk neutrality, $U_{i c_{i} c_{i}}=0$ and $\varepsilon_{i}=0$. 
solutions. That is, in the presence of rent seeking, in equilibrium, we assume that time is allocated to labor, leisure and rent seeking.

\section{Risk neutrality}

Under risk neutrality, equations (12) and (13) are independent, with $x^{*}$ chosen in the Nash equilibrium of the rent-seeking game (the solution to (13)) and $l_{R}^{*}$ chosen to maximize expected utility with the marginal rate of subsitution between leisure and expected consumption equal to the net-of-tax wage $W$ as indicated by (12). With risk neutrality, in equilibrium, we have: ${ }^{10}$

$$
(\beta W+1) x^{*}<\frac{V}{n}
$$

The following lemma compares leisure of risk-neutral individuals who respectively confront and do not confront a rent-seeking opportunity.

Lemma 1: For risk neutrality, $l_{R}^{*}>l_{N R}^{*}$ if leisure is a normal good, $l_{R}^{*}=l_{N R}^{*}$ if leisure is a neutral good, and $l_{R}^{*}<l_{N R}^{*}$ if leisure is an inferior good.

Proof: With risk neutrality, because $U_{c c}=0,(4)$ implies that leisure is a normal, neutral or inferior good, according to whether $U_{l c}<0$, respectively. From inequality (14), it follows that $C\left(l_{N R}^{*}\right)<\tilde{C}\left(x^{*}, l_{N R}^{*}\right)$. Substituting $x^{*}$ and

\footnotetext{
${ }^{10}$ The LHS of (14) is the alternative cost of time and resources foregone in participating in rent seeking and the RHS is the expected rent. In an interior equilibrium in which an individual chooses to participate in rent seeking, the expected return from the contest is greater than the alternative cost of resources.
} 
$l_{N R}^{*}$ into (12) results in $\frac{\partial \tilde{U}}{\partial l} \geq 0$ if leisure is respectively a normal, neutral or inferior good. From the second order conditions for expected-utility maximization, we have $\frac{\partial^{2} \tilde{U}}{\partial l^{2}}<0$, and thus, $l_{R}^{*}>l_{N R}^{*}$ as leisure is respectively normal, neutral or inferior. QED

We now show that:

\section{Proposition 1:}

For leisure non-inferior, under risk neutrality, a rent-seeking opportunity increases the excess burden of taxation.

Proof: Let $\tilde{U}_{R}^{*}(W)$ and $U_{N R}^{*}(W)$ be the indirect utility when an individual respectively confronts and does not confront a rent-seeking opportunity. Denote by $e\left(W, \tilde{U}_{R}^{*}\right)$ and $e\left(W, U_{N R}^{*}\right)$ the corresponding expenditure functions. In the absence of a rent seeking opportunity, the equivalent variation is:

(15) $\Psi_{N R}=e\left(W_{b}, U_{N R}^{*}\left(W_{b}\right)\right)-e\left(W_{b}, U_{N R}^{*}\left(W_{a}\right)\right)$,

where $W_{a}=W_{b}(1-t)$ with $t$ the tax rate on productively earned income. The excess burden of taxation in the absence of rent seeking is:

$$
S_{N R}=\Psi_{N R}-t W_{b} L_{N R}^{*}\left(W_{a}\right),
$$

where $L_{N R}^{*}\left(W_{a}\right)$ is the time assigned to productive work in the absence of a rent seeking opportunity. Correspondingly, the excess burden in the presence of the rent-seeking opportunity is: 


$$
S_{R}=\Psi_{R}-t W_{b} L_{R}^{*}\left(W_{a}\right)=e\left(W_{b}, \tilde{U}_{R}^{*}\left(W_{b}\right)\right)-e\left(W_{b}, \tilde{U}_{R}^{*}\left(W_{a}\right)\right)-t W_{b} L_{R}^{*}\left(W_{a}\right),
$$

where $L_{R}^{*}(W)$ is the time assigned to work. With risk neutrality:

$$
\Delta e\left(W_{a}\right)=e\left(W_{a}, \tilde{U}_{R}^{*}\left(W_{a}\right)\right)-e\left(W_{a}, U_{N R}^{*}\left(W_{a}\right)\right)=P\left(x_{1}^{*}\left(W_{a}\right), \cdots, x_{n}^{*}\left(W_{a}\right)\right) V-\left(1+\beta W_{a}\right) x^{*}\left(W_{a}\right),
$$

where $x_{1}^{*}\left(W_{a}\right)=x_{2}^{*}\left(W_{a}\right)=\cdots \cdots=x_{n}^{*}\left(W_{a}\right)=x^{*}\left(W_{a}\right)$.

Thus, in a symmetric Nash equilibrium,

(19) $\frac{d \Delta e}{d W}=-\left(\beta x^{*}(W)+(1+\beta W) \frac{\partial x^{*}(W)}{\partial W}\right) \cdot{ }^{11}$

${ }^{11} \sum_{i=1}^{n} P_{i}=1$ and by symmetry $d x_{i}=d x_{j}=d x, \frac{\partial P_{i}}{\partial x_{j}}=\frac{\partial P_{j}}{\partial x_{i}}=\frac{\partial P_{k}}{\partial x_{l}}, \quad \frac{\partial x_{i}}{\partial W}=\frac{\partial x}{\partial W}$ and $\frac{\partial P_{i}}{\partial x_{i}}=\frac{\partial P_{j}}{\partial x_{j}} \forall i, j, k, l . \quad$ Therefore,

$\sum_{j=1}^{n} \sum_{i=1}^{n} \frac{\partial P_{i}}{\partial x_{j}} d x_{j}=\left(n \frac{\partial P_{k}}{\partial x_{k}}+n(n-1) \frac{\partial P_{k}}{\partial x_{l}}\right) d x=0 \forall k, l$

$\sum_{j=1}^{n} \frac{\partial P_{i}}{\partial x_{j}}=\frac{\partial P_{i}}{\partial x_{i}}+(n-1) \frac{\partial P_{i}}{\partial x_{k}}=0 \quad \forall i, k$

$\frac{d P}{d W}=\frac{d P_{i}}{d W}=\sum_{j=1}^{n} \frac{\partial P_{i}}{\partial x_{j}} \frac{\partial x_{j}}{\partial W}=\frac{\partial x}{\partial W} \sum_{j=1}^{n} \frac{\partial P_{i}}{\partial x_{j}}=0 \forall i$

Because $\frac{d P}{d W}=0$, the expected rent $P V$ does not change with $W$ and in equilibrium is equal to $\frac{V}{n}$. Yet, with $p_{x}=(1+\beta W)$, which is the price of one unit of rent seeking $x$, $\frac{d x^{*}}{d W}=\frac{d x^{*}}{d p_{x}} \frac{d p_{x}}{d W}=\beta \frac{d x^{*}}{d p_{x}}$ and the change in the expenditure on rent seeking is $\frac{d\left(p_{x} x^{*}\right)}{d W}=\beta\left(p_{x} \frac{d x^{*}}{d p_{x}}+x^{*}\right) \underset{<}{<} 0$ as the elasticity $E_{x / p_{x}}=\frac{d x^{*}}{d p_{x}} \frac{p_{x}}{x^{*}} \frac{\geq}{<}-1$. Thus, $\frac{d \Delta e}{d W} \leq 0$ according to whether $E_{x / p_{x}} \frac{\geq}{<}-1$. 
Applying the mean value theorem on (19) results in:

(20) $\frac{\Delta e\left(W_{b}\right)-\Delta e\left(W_{a}\right)}{\left(W_{b}-W_{a}\right)}=\frac{d \Delta e}{d W}\left(W_{c}\right)=-\left(\beta x^{*}\left(W_{c}\right)+\left(1+\beta W_{c}\right) \frac{\partial x^{*}\left(W_{c}\right)}{\partial W}\right)$, where $W_{a}<W_{c}<W_{b}$

The difference in the excess burden with and without a rent seeking opportunity is:

$$
\begin{aligned}
\Delta S & =S_{R}-S_{N R} \\
& =\Delta e\left(W_{b}\right)-\Delta e\left(W_{a}\right)+t W_{b}\left(L_{N R}^{*}\left(W_{a}\right)-L_{R}^{*}\left(W_{a}\right)\right) .
\end{aligned}
$$

Substituting (20) and $L_{N R}^{*}\left(W_{a}\right)-L_{R}^{*}\left(W_{a}\right)=l_{R}^{*}\left(W_{a}\right)-l_{N R}^{*}\left(W_{a}\right)+\beta x^{*}\left(W_{a}\right)$ into (21) we have:

(22) $\Delta S=t W_{b} \beta\left(x^{*}\left(W_{a}\right)-x^{*}\left(W_{c}\right)\right)+t W_{b}\left(l_{R}^{*}\left(W_{a}\right)-l_{N R}^{*}\left(W_{a}\right)\right)-t W_{b}\left(1+\beta W_{c}\right) \frac{\partial x^{*}\left(W_{c}\right)}{\partial W}$

Applying the implicit function theorem in (13) results in:

(23) $\quad \frac{\partial x^{*}}{\partial W}=\frac{\beta}{\frac{\partial^{2} P}{\partial x^{2}} V}<0$

From (23), it follows that the first and the third terms on the RHS of (22) are positive. From lemma 1, with leisure non-inferior, the second term is nonnegative. Therefore, if leisure is non-inferior, $\Delta S>0 .{ }^{12}$ QED

Using the equivalent variation $\Psi$, the excess burden of taxation $S$ is the amount in excess of taxes $R=t W_{b} L^{*}\left(W_{a}\right)$ that an individual is willing to pay to return to a no-tax state (Mohring, 197l) - which is obtained by

12 When leisure is inferior, because the second term in (22) is negative, the effect of rent seeking on the excess burden of taxation is ambiguous. 
deducting the taxes paid $R$ from the total amount that the individual is willing to pay $\Psi$ to avoid the tax. That is, $S=\Psi-R$. $\Psi$ is smaller, unchanged or greater with rent seeking according to whether the elasticity of demand for rent seeking is smaller, equal or greater than one and is not conclusive (see footnote 11). However, in the presence of rent seeking, $R$ declines because of the substitution from time spent earning taxable income to rent seeking and also substitution to leisure if leisure is normal. A rent-seeking opportunity also increases expected income. In the proof for proposition 1, we have shown that, with leisure non-inferior, the combination of the change in $\Psi$ and the decline in $R$ always results in an increase in the excess burden of taxation $S$ in the presence of rent seeking.

\section{Risk aversion}

We now introduce risk aversion. After-tax income and leisure are available with certainty but the rent is uncertain or subject to risk. With additive constant absolute risk aversion (CARA) utility, the result for risk neutrality in lemma 1 that leisure increases with rent seeking is replicated (lemma 2). Under these conditions, the result under risk neutrality in proposition 1 that rent seeking increases the excess burden of taxation is also replicated (proposition 2).

Under risk aversion,

$$
P U\left(C^{V}, l\right)+(1-P) U\left(C^{-V}, l\right)-U\left(C^{-V}+P V-\varepsilon, l\right)=0,
$$


where $\varepsilon\left(x^{*}\left(W_{a}\right), P, l_{R}^{*}\left(W_{a}\right), W_{a}, V, M\right)>0$. Applying the implicit function theorem in (24) given that $U_{c l}=0$ results in:

$$
\begin{aligned}
& \frac{\partial \varepsilon}{\partial x}=\frac{\partial \varepsilon}{\partial P} \frac{\partial P}{\partial x}+\varepsilon_{x} \\
& =\left(\frac{\left(U\left(C^{-V}, l\right)-U\left(C^{V}, l\right)\right)}{U_{c}(\tilde{C}, l)}+V\right) \frac{\partial P}{\partial x}+(1+\beta W) \frac{E U_{c}-U_{c}\left(C^{-V}+P V-\varepsilon, l\right)}{U_{c}(\tilde{C}, l)}
\end{aligned}
$$

$$
\frac{\partial \varepsilon}{\partial V}=P \frac{U_{c}(\tilde{C}, l)-U_{c}\left(C^{V}, l\right)}{U_{c}(\tilde{C}, l)}>0
$$

$$
\frac{\partial \varepsilon}{\partial W}=-(\bar{T}-l-\beta x) \frac{E U_{c}-U_{c}\left(C^{-V}+P V-\varepsilon, l\right)}{U_{c}(\widetilde{C}, l)}
$$

and

$$
\frac{\partial \varepsilon}{\partial l}=\frac{W E U_{c}-W U_{c}(\tilde{C}, l)-P U_{l}\left(C^{V}, l\right)-(1-P) U_{l}\left(C^{-V}, l\right)+U_{l}(\tilde{C}, l)}{U_{c}(\tilde{C}, l)},
$$

where $E U_{c}=U_{c}\left(C^{-V}+P V-\hat{\varepsilon}, l\right)$.

$U_{c l}=0$ implies that $P U_{l}\left(C^{V}, l\right)+(1-P) U_{l}\left(C^{-V}, l\right)=U_{l}(\tilde{C}, l)$ and thus:

$$
\frac{\partial \varepsilon}{\partial l}=W \frac{E U_{c}-U_{c}\left(C^{-V}+P V-\varepsilon, l\right)}{U_{c}(\tilde{C}, l)}
$$

With CARA utility, we have,

$$
E U_{c}=U_{c}\left(C^{-V}+P V-\hat{\varepsilon}, l\right)=U_{c}\left(C^{-V}+P V-\varepsilon, l\right) .{ }^{13}
$$

${ }^{13}$ The risk premium $\varepsilon$ associated with $U$ is proportional to the measure of absolute risk aversion, $r(C, l)=-\frac{U_{c c}}{U_{c}}$, and the risk premium $\hat{\varepsilon}$ associated with $-U_{c}$, is proportional to the measure of absolute risk aversion, $\hat{r}(C, l)=-\frac{U_{c c c}}{U_{c c}}$. A necessary and sufficient condition for $\hat{\varepsilon}=\varepsilon$ is $\hat{r}(C, l)=-\frac{U_{c c c}}{U_{c c}}=r(C, l)=-\frac{U_{c c}}{U_{c}}$ or alternatively, $U_{c} U_{c c c}-U_{c c}^{2}=0$, which is a necessary and sufficient condition for CARA. See Kimball (1990) for "absolute prudence". 
Substituting (30) into (25), (27) and (29) result in:

(31) $\frac{\partial^{2} \varepsilon}{\partial l \partial x}=\frac{\partial \varepsilon}{\partial l}=\frac{\partial \varepsilon}{\partial W}=0$

(32) $\varepsilon_{x}=(1+\beta W) \frac{E U_{c}-U_{c}\left(C^{-V}+P V-\varepsilon, l\right)}{U_{c}(\tilde{C}, l)}=0$,

and

(33) $\frac{\partial \varepsilon}{\partial x}=\left(\frac{\left(U\left(C^{-V}, l\right)-U\left(C^{V}, l\right)\right)}{U_{c}(\tilde{C}, l)}+V\right) \frac{\partial P}{\partial x}$.

\section{Lemma 2:}

If $U_{c l}=0$ (i.e., additive utility) and CARA then: ${ }^{14}$

$l_{R}^{*}>l_{N R}^{*}$

Proof:

From (31) it follows that with additive CARA utility, equations (11) and (12) are independent. Therefore, applying the implicit function theorem in (12) results in:

(34) $\frac{\partial l_{R}^{*}}{\partial V}=-\frac{\frac{\partial^{2} \tilde{U}}{\partial V \partial l}}{\frac{\partial^{2} \tilde{U}}{\partial l^{2}}}=\frac{\left(P-\frac{\partial \varepsilon}{\partial V}\right) W U_{\tilde{c} \tilde{c}}}{\frac{\partial^{2} \tilde{U}}{\partial l^{2}}}$.

Substituting (26) into (34) result in:

$$
\frac{\partial l_{R}^{*}}{\partial V}=\frac{P \frac{U_{c}\left(C^{V}, l\right)}{U_{c}(\tilde{C}, l)} W U_{\tilde{c} \tilde{c}}}{\frac{\partial^{2} \tilde{U}}{\partial l^{2}}}
$$

${ }^{14}$ Note that under risk aversion $U_{c l} \geq 0$ implies that leisure is a normal good. 
With $U_{\tilde{c} \tilde{c}}<0$ and the second order condition $\frac{\partial^{2} \tilde{U}}{\partial l^{2}}<0$ we obtain that $\frac{\partial l_{R}^{*}}{\partial V}>0$.

Therefore:

(36) $\quad l_{R}^{*}(V)-l_{N R}^{*}=l_{R}^{*}(V)-l_{R}^{*}(0)=\int_{0}^{V} \frac{\partial l_{R}^{*}}{\partial V} d V>0 \cdot{ }^{15} \quad$ QED

\section{Proposition 2}

With additive CARA utility, the presence of rent seeking increases the excess burden of taxation.

Proof: With risk aversion equation (18) is

$$
\Delta e\left(W_{a}\right)=P\left(x_{1}^{*}\left(W_{a}\right), \cdots, x_{n}^{*}\left(W_{a}\right)\right) V-\varepsilon\left(x^{*}\left(W_{a}\right), P, l_{R}^{*}\left(W_{a}\right), W_{a}, V, M\right)-\left(1+\beta W_{a}\right) x^{*}\left(W_{a}\right),
$$

where $x_{1}^{*}\left(W_{a}\right)=x_{2}^{*}\left(W_{a}\right)=\cdots \cdots=x_{n}^{*}\left(W_{a}\right)=x^{*}\left(W_{a}\right)$.

Thus, in a symmetric Nash equilibrium,

$$
\frac{d \Delta e}{d W}=-\left(\beta x^{*}(W)+(1+\beta W) \frac{\partial x^{*}(W)}{\partial W}+\frac{d \varepsilon}{d W}\right)
$$

where

(39) $\frac{d \varepsilon}{d W}=\varepsilon_{x} \frac{\partial x}{\partial W}+\frac{\partial \varepsilon}{\partial P} \frac{d P}{d W}+\frac{\partial \varepsilon}{\partial l} \frac{\partial l}{\partial W}+\frac{\partial \varepsilon}{\partial W}$.

With additive CARA utility, (31) and (32) imply that:

(40) $\frac{d \varepsilon}{d W}=0 .{ }^{16}$

${ }^{15}$ Notice that if $V=0$ then $x^{*}=0$ and $l_{R}^{*}(0)=l_{N R}^{*}$.

${ }^{16}$ Notice that $\frac{d P}{d W}=0$. See the proof in footnote 11 . 
Substituting (40) into (38) results in:

(41) $\frac{d \Delta e}{d W}=-\left(\beta x^{*}(W)+(1+\beta W) \frac{\partial x^{*}(W)}{\partial W}\right)$.

With additive CARA utility, equation (22) is:

(42) $\Delta S=t W_{b} \beta\left(x^{*}\left(W_{a}\right)-x^{*}\left(W_{c}\right)\right)+t W_{b}\left(l_{R}^{*}\left(W_{a}\right)-l_{N R}^{*}\left(W_{a}\right)\right)-t W_{b}\left(1+\beta W_{c}\right) \frac{\partial x^{*}\left(W_{c}\right)}{\partial W}$.

From lemma 2, under additive CARA utility, $l_{R}^{*}>l_{N R}^{*}$, that is, the second term on the RHS of (42) is positive. With additive CARA utility, equations (11) and (12) are independent. Therefore, applying the implicit function theorem in (13) and taking into account (31) and (33), results in:

$$
\frac{\partial x}{\partial W}=\frac{\beta}{\frac{\partial^{2} P}{\partial x^{2}} V-\frac{\partial^{2} \varepsilon}{\partial x^{2}}}=\frac{\beta U_{c}(\tilde{C}, l)}{\frac{\partial^{2} P}{\partial x^{2}}\left(U\left(C^{V}, l\right)-U\left(C^{-V}, l\right)\right)}<0 .{ }^{17}
$$

(43) implies that the first and the third terms on the RHS of (42) are also positive. Thus, with $C A R A$ and $U_{c l}=0$, the excess burden of taxation is greater in the presence of rent seeking. QED

With risk aversion, the valuation of the uncertain income from rent seeking (i.e., the change in risk premium) due to the tax on earned income in

$$
\begin{aligned}
& \text { Notice that with additive CARA (i.e., } \left.U(C, l)=-\beta e^{-a C}+f(l)\right) \text {, } \\
& \frac{\partial^{2} \varepsilon}{\partial x^{2}}=\frac{\partial^{2} P}{\partial x^{2}}\left(\frac{\left(U\left(C^{-V}, l\right)-U\left(C^{V}, l\right)\right)}{U_{c}(\tilde{C}, l)}+V\right) .
\end{aligned}
$$


principle affects the excess burden of taxation. With additive CARA utility, the valuation of the uncertain income does not change. ${ }^{18}$

\section{Conclusions}

\subsection{Other rent seeking contests}

We have shown that, under risk neutrality and for additive constant absolute risk aversion utility, when rent seekers can earn taxed income, the social costs of rent seeking include an increased excess burden of taxation. We have derived our results using a standard model in which rent seeking is an individual activity in quest of a personally assigned indivisible private benefit. Extensions to rent seeking by interest groups to include shared rents, public good benefits, and rent seeking as a collective activity require respecification of the rent-seeking contest. ${ }^{19}$ Our results are general in applying to group activities. Whatever time and resources are used in rent seeking, individuals confronting the opportunity of participation in rent seeking are subject to the income and substitution effects that we have described and that increase the excess burden of taxation including in the case of risk aversion

\footnotetext{
${ }^{18}$ That is, with an additive CARA utility $\frac{d \varepsilon}{d W}=0$.
}

${ }^{19}$ Long and Vousden (1987) describe private benefits shared by a group, Ursprung (1990) describes rents that provide group public-good benefits, and Nitzan (1991) describes collectively provided inputs into rent seeking. See also Congleton, Hillman, and Konrad (2008, volume 1, part 2) and Ursprung (2012). 
the risk premium that discounts the individual's uncertain income from rent seeking. Our conclusions are also independent of the means of measurement of social loss from rent seeking. Indirect means of measuring the social losses from rent seeking have been proposed by Sobel and Garrett (2002), who suggest using differences in allocation of resources in the regions of capital cities where political decisions are made and other regions. Katz and Rosenberg (1989) suggested using changes in the government budget as an approach to measuring rent seeking. Whatever the social cost of rent seeking through time and other resources used in rent seeking, the excess burden of taxation is greater because of rent seeking.

\subsection{Applications}

Our model of people earning taxable income and confronting rent-seeking opportunties applies to a wide range of circumstances. Distraction from earning taxable income may occur through the opportunity to influence assignment of budgetary revenue (Park, Philippopoulos, and Vassilatos, 2005) or government officials may offer rent sharing through sale of state assets at privileged prices (Gelb, Hillman, and Ursprung, 1998). Political decision makers may be subject to influence regarding environmental policies (Dijkstra, 1999), the designation of beneficiaries of monopoly or protectionist rents (Peltzman, 1976; Hillman, 1989; Grossman and Helpman, 2001), or regarding determination of land values through land rezoning (Altshuler and Gómez-Ibáňez, 1993). Productively engaged researchers may find themselves 
with the opportunity to compete for a research or travel grant that would yield private but not social benefit. Individuals employed in a government bureaucacy may confront opportunities to influence their pomotion prospects (Kahana and Liu, 2010). Quite generally, rent seekers in general have options for income from other than rent seeking and where such income is taxed our conclusions apply. ${ }^{20}$

\subsection{Separation between rent seeking and public finance}

Rent seeking and taxation both involve efficiency losses due to government but have been the focus of attention of separate literatures. Rent seeking has been a topic in the context of a public-choice or political-economy view of government. The efficiency loss due to the excess burden of taxation, also known as deadweight loss, has been traditionally studied in a classical publicfinance context (see Ballard and Fullerton, 1992; Slemrod and Yitzhaki; 2001; Auerbach and Hines, 2002). Recent studies have departed from the separation between rent seeking and public finance. Baldacci, Hillman, and Kojo (2004) found that, for 39 low-income countries, contraction of public spending increases growth, which is attributed to the diminished incentives for rent

\footnotetext{
${ }^{20}$ A rent-seeking opportunity may be due to new rent creation or the rent can have been preexisting but not previously contestable. On rents that are assigned for limited duration and the change from a non-contestable to a contestable rent, see Aidt and Hillman (2008). We set aside the ethical aversion to participation in rent seeking as described by Guttman, Nitzan, and Spiegel (1992).
} 
seeking because of a smaller size of government. Park, Philippopoulos, and Vassilatos (2005) found, from a study of 108 countries, that rent seeking is positively related to the size of the public sector and proposed that incentives for rent seeking imply lower socially desirable taxation and smaller size of government. Rothschild and Scheuer (2011) take the same point further by introducing rent seeking into the normative public-finance model of optimal taxation. They show that, when asymmetric information prevents a government from knowing with certainty whether individuals are engaged in rent seeking or productive activity, optimal taxation of income is lower because of substitution incentives to rent seeking. ${ }^{21}$ These studies do not however consider the consequences for social loss of the interdependence between rent seeking and the excess burden of taxation.

\subsection{The size of government}

Our results indicate that independent computations of the excess burden of taxation and social losses from rent seeking are lower bounds for social costs. ${ }^{22}$ The increased social losses because of the greater excess burden of

\footnotetext{
${ }^{21}$ The model requires benevolent government officials or political decision makers who are concerned with maximizing social welfare as was Mirrlees and other officials or political decision makers who benefit from rent creation and rent assignment.

22 See Stuart (1984), Browning (1987), Fullerton (1991), and Goulder and Williams (2003) for computations of the excess burden of taxation. For estimates of the social cost of rent seeking, see Laband and Sophocleus (1992) for the United States and Angelopoulos, Philippopoulos, and Vassilatos (2009) for Europe.
} 
taxation in the presence of rent seeking indicate a smaller socially desirable size and scope of government when rent seeking takes place. ${ }^{23}$

\subsection{Insitutions and political discretion}

Rent seeking takes place in different institutional contexts (Congleton, 1980, 2011). Because of the increased burden of taxation, social costs of privileged rent extraction (see Tullock, 1989; Murphy, Shleifer, and Vishny, 1993; Gelb, Hillman, and Ursprung, 1998; Cheikbossian, 2003) have been higher than noted. In low-income countries, where contestable rents have included personal gain from corruption and personal benefit from the distribution of foreign aid (for example, see Pedersen, 1997; Easterly, 2001; Svensson, 2000) social costs of rent seeking have likewise been higher. The interdependence between the excess burden of taxation and rent seeking implies, quite generally, greater social benefit from diminished political discretion to assign rents in both high and low-income countries.

\footnotetext{
${ }^{23}$ For influences on the size of government, see Tridimas and Winer (2005) and Hillman (2009, chapter 10). Facchini and Melki (2013) provide an example of empirical compution of the efficient size of government.
} 


\section{References}

Aidt, T., Hillman, A.L., 2008. Enduring rents. European Journal of Political Economy, 24, $454-53$.

Altshuler, A.A. and Gómez-Ibáňez, J.A., 1993. Regulation for Revenue: The Political Economy of Land Use Extractions. Brookings Institute, Washington DC, and the Lincoln Institute for Land Policy, Cambridge MA.

Angelopoulos, K., Philippopoulos, A., Vassilatos, V., 2009. The social cost of rent seeking in Europe. European Journal of Political Economy 25, 280-299.

Auerbach, A.J., Hines, J.R. Jr., 2002. Taxation and economic efficiency. In Auerbach, A.J. and Feldstein, M. (Eds.), Handbook of Public Economics, volume 3, North-Holland, Amsterdam, pp. 1347-1421.

Baldacci, E., Hillman, A.L., Kojo, N., 2004. Growth, governance, and fiscalpolicy transmission channels in low-income countries. European Journal of Political Economy 20, 517 - 549. Reprinted in: Gupta, S., Clements, B., Inchauste, G. (Eds.), 2004, Helping Countries Develop: The Role of Fiscal Policy. International Monetary Fund, Washington DC, pp. 67 - 104.

Ballard, C. L., Fullerton, D., 1992. Distortionary taxes and the provision of public goods. Journal of Economic Perspectives 6, 117-31.

Becker, G.S., 1965. A theory of the allocation of time. Economic Journal 75, $493-517$.

Browning, E.K., 1987. On the marginal welfare cost of taxation. American 
Economic Review 77, 11-23.

Cheikbossian, G., 2003. Property rights, rent seeking, and aggregate outcomes in transition economies. Economic Systems 27, 271-288.

Congleton, R.D., 1980. Competitive process, competitive waste, and institutions. In Buchanan, J., Tollison, R.D., and Tullock, G. (Eds.), Towards a Theory of the Rent-Seeking Society. Texas A\&M Press, College Station, pp. 153 - 179. Reprinted in: Congleton, R.D., Hillman, A.L., Konrad, K.A. (Eds.), 2008. Forty Years of Research on Rent Seeking 1 - The Theory of Rent Seeking. Springer, Heidelberg, pp. 69-95.

Congleton, R.D., 2011. Perfecting Parliament: Constitutional Reform, Liberalism, and the Rise of Western Democracy. Cambridge University Press, New York NY.

Congleton, R.D., Hillman, A.L., Konrad, K.A. (Eds.), 2008. Overview. In: Forty Years of Research on Rent Seeking 1 - The Theory of Rent Seeking. Springer, Heidelberg, pp. 1-42.

Dijkstra, B. R., 1999. The Political Economy of Environmental Policy: A Public Choice Approach to Market Instruments. Edward Elgar, Cheltenham U.K.

Domar, E.D., Musgrave, R.A., 1944. Proportional income taxation and risktaking. The Quarterly Journal of Economics 58, 388-422.

Easterly, W., 2001. The Elusive Quest for Growth: Economists' Adventures and Misadventures in the Tropics. MIT Press, Cambridge MA. 
Epstein, G.S., Hefeker, C., 2003. Lobbying contests with alternative instruments. Economics of Governance 4, 81 - 89.

Facchini, F., Melki, M., 2013. Efficient government size: France in the $20^{\text {th }}$ century. European Journal of Political Economy 31, 1-14.

Fullerton, D., 1991. Reconciling recent estimates of the welfare cost of taxation. American Economic Review 81, 302-308.

Gelb, A., Hillman, A.L., Ursprung, H.W., 1998. Rents as distractions: Why the exit from transition is prolonged. In: Baltas, N.C., Demopoulos, G., Hassid, J. (Eds.), Economic Interdependence and Cooperation in Europe, Springer, Heidelberg, pp. $21-38$.

Glazer, A., Konrad, K.A., 1999. Taxation of rent-seeking activities. Journal of Public Economics 72, 61-72.

Goulder, L.H., Williams, R.C. III, 2003. The substantial bias from ignoring general equilibrium effects in estimating excess burden, and a practical solution. Journal of Political Economy 111, 898-927.

Grossman, G.M., Helpman, E., 2001. Special Interest Politics. MIT Press, Cambridge MA.

Guttman, J. M., Nitzan, S., Spiegel, U., 1992. Rent seeking and social investment in taste change. Economics and Politics 4, 31-42.

Harberger, A.C., 1964. The measurement of waste. The American Economic Review (Papers and Proceedings) 54, 58-76. 
Hausman, J.A., 1981. Exact consumer's surplus and deadweight loss. American Economic Review 71, 662-676.

Hillman, A.L., 1989. The Political Economy of Protection. Harwood, Chur. Reprinted in 2001 by Routledge, London.

Hillman, A.L., 2009. Public Finance and Public Policy: Responsibilities and Limitations of Government (2nd Edition). Cambridge University Press, New York NY.

Hillman, A.L., 2013. Rent seeking. In Reksulak, M., Razzolini, L., Shughart, W.F. II (Eds.), The Elgar Companion to Public Choice (2nd Edition). Edward Elgar, Cheltenham U.K., pp. 307-330.

Hillman, A.L., Katz, E., 1984. Risk-averse rent seekers and the social cost of monopoly power. Economic Journal 94, 104 - 110. Reprinted in: Congleton, R.D., Hillman, A.L., Konrad, K.A. (Eds.), 2008. Forty Years of Research on Rent Seeking 1 - The Theory of Rent Seeking. Springer, Heidelberg, 2008, pp. 97 - 103.

Hines, J.R., Jr. 1999. Three sides of Harberger triangles. Journal of Economic Perspectives 13, 167-188.

Kahana, N., Liu, Qijun, 2010. Endemic corruption. European Journal of Political Economy 26, 82-88.

Katz, E., Rosenberg, J., 1989. Rent-seeking for budgetary allocation: Preliminary results for 20 countries. Public Choice 60, 133-144.

Kimball, M.S., 1990. Precautionary Saving in the Small and in the Large. Econometrica 58, 53-73. 
Konrad, K.A., 2009. Strategy and Dynamics in Contests. Oxford University Press, Oxford U.K.

Konrad, K.A., Schlesinger, H., 1997. Risk aversion in rent-seeking and rentaugmenting games. Economic Journal 107, 1671-1683.

Laband, D.N., Sophocleus, J.P., 1992. An estimate of resource expenditure on transfer activity in the United States. Quarterly Journal of Economics 107, 959-983.

Long, N.V., Vousden, N., 1987. Risk-averse rent seekers and shared rents. Economic Journal 97, 971 - 985. Reprinted in: Congleton, R.D., Hillman, A.L., Konrad, K.A. (Eds.), 2008. Forty Years of Research on Rent Seeking 1 - The Theory of Rent Seeking. Springer, Heidelberg, 2008, pp. 293-307.

Long, N.V., 2013. The theory of contests: a unified model and review of the literature. European Journal of Political Economy 32, 161-181. Reprinted in: Congleton, R.D., Hillman, A.L., Konrad, K.A. (Eds.), 2008. Forty Years of Research on Rent Seeking 1 - The Theory of Rent Seeking. Springer, Heidelberg, 2008, pp. 293-307.

Mohring, H., 1971. Alternative welfare gain and loss measures. Western Economic Journal 9, 349-368.

Murphy, K.M., Shleifer, A., Vishny, R.W, 1993. Why is rent-seeking so costly to growth? The American Economic Review 83, 409-414. Reprinted in: Congleton, R.D., Hillman, A.L., Konrad, K.A. (Eds.), 2008. Forty Years of Research on Rent Seeking 2 - Application: rent seeking in practice. Springer, Heidelberg, 2008, pp. 213-218. 
Nitzan, S., 1991. Collective rent dissipation. Economic Journal 101, 1522-1534. Reprinted in: Congleton, R.D., Hillman, A.L., Konrad, K.A. (Eds.), 2008. Forty Years of Research on Rent Seeking 1 - The Theory of Rent Seeking. Springer, Heidelberg, 2008, pp. 309-328.

Park, H., Philippopoulos, A., Vassilatos, V., 2005. Choosing the size of the public sector under rent seeking from state coffers. European Journal of Political Economy 21, 830-850.

Pedersen, K.A., 1997. The political economy of distribution in developing countries: A rent-seeking approach. Public Choice 91, 351-373.

Peltzman, S., 1976. Toward a more general theory of regulation. Journal of Law and Economics 19, 171-240.

Rothschild, C., Scheuer, F., 2011. Optimal taxation with rent-seeking. NBER Working Paper 17035. Cambridge MA.

Schuster, P., Schmitt, C., Traub, S., 2013. The retreat of the state from entrepreneurial activities: A convergence analysis for OECD countries, 1980-2007. European Journal of Political Economy 32, 95-112.

Skaperdas, S., Gan, L., 1995. Risk aversion in contests. Economic Journal 105, 951-962.

Slemrod, J. B., Yitzhaki, S., 2001. The marginal cost of funds and the marginal benefit of projects. National Tax Journal 54, 189-201.

Sobel, R. S., Garrett, T., 2002. On the measurement of rent seeking and its social opportunity cost. Public Choice 112, 115-136. 
Stuart, C., 1984. Welfare costs per additional dollar of tax revenue in the United States. American Economic Review 74, 352-362.

Svensson, J., 2000. Foreign aid and rent seeking. Journal of International Economics 51, 437-461. Reprinted in: Congleton, R.D., Hillman, A.L., Konrad, K.A. (Eds.), 2008. Forty Years of Research on Rent Seeking 2 Applications: Rent Seeking in Practice, Springer, Heidelberg, pp. 165-189.

Treich, N., 2010. Risk-aversion and prudence in rent-seeking games. Public Choice 145, 339-349.

Tridimas, G., Winer, S.L., 2005. The political economy of government size. European Journal of Political Economy 21, 643-666.

Tullock, G., 1967. The welfare costs of tariffs, monopoly, and theft. Western Economic Journal 5, 224-232. Reprinted in: Congleton, R.D., Hillman, A.L., Konrad, K.A. (Eds.), 2008. Forty Years of Research on Rent Seeking 1 - The Theory of Rent Seeking. Springer, Heidelberg, pp. 45-53.

Tullock, G., 1989. The Economics of Special Privilege and Rent Seeking. Kluwer Academic Publishers, Boston.

Ursprung, H.W., 1990. Public goods, rent dissipation, and candidate competition. Economics and Politics 2, 115-132. Reprinted in: Reprinted in: Congleton, R.D., Hillman, A.L., Konrad, K.A. (Eds.), 2008. Forty Years of Research on Rent Seeking 1 - The Theory of Rent Seeking. Springer, Heidelberg, pp. 329-346.

Ursprung, H.W., 2012. The evolution of sharing rules in rent seeking contests: incentives crowd out cooperation. Public Choice 153, 149-161. 
Weiss, Y., 2009. Work and Leisure: A History of Ideas. Journal of Labor Economics 27, 1-20.

Willig, R.D., 1976. Consumer's surplus without apology. American Economic Review, 66, 589-597. 